\title{
Acute Oral Manifestations in Patients Submitted to Radiotherapy in the Head and Neck Region: Literature Narrative Review
}

\section{Manifestações Orais Agudas em Pacientes Submetidos à Radioterapia em Região de Cabeça e Pescoço: Revisão Narrativa da Literatura}

\author{
Taís Correia da Conceição ; Ana Carla Barletta Sanches ; Tila Fortuna Costa Freire; Gabriela Botelho Martins ; \\ Marcelo Victor Coelho Marques ${ }^{\text {d }}$; Juliana Borges de Lima Dantas*bd \\ ${ }^{a}$ Centro Universitário Regional do Brasil, Dentistry Course. BA, Brazil, \\ bUniversidade Federal da Bahia, Programa de Pós-Graduação Stricto Sensu em Processos Interativos de Órgãos e Sistemas, BA. Brazil \\ ${ }^{c}$ Universidade Federal da Bahia, Instituto de Ciências da Saúde.BA, Brazil.

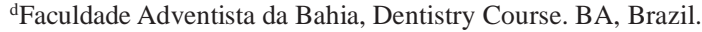 \\ *E-mail: judyborges@gmail.com.
}

\begin{abstract}
The use of ionizing radiation, affects not only malignant cells but also healthy tissues, and promotes several side acute or late effects in the oral cavity. Among the acute effects, oral mucositis, xerostomia, hyposalivation, dysgeusia and dysphagia present a prominent role. The present study aims to conduct a narrative literature review on radiotherapy in the head and neck region as a therapeutic modality for cancer in this region and the main acute oral manifestations and their respective treatments. This was an exploratory literature review, through the database of Scielo, Pubmed, Medline and institutional websites using the crossing of the descriptors in English and Portuguese "head and neck neoplasms", "radiotherapy", "xerostomia", "dysgeusia" and "dysphagia". According to the established criteria, a total of 46 articles and 2 institutional websites were selected from the databases, and one book was added for presenting relevance on this theme. The results demonstrate that oral mucositis is the most prevalent acute effect and has a direct impact on patient's quality of life, but there is no gold standard treatment. Dysphagia, xerostomia, hyposalivation and dysgeusia are common manifestations in irradiated patients, and present several therapeutic modalities. Given the importance of side effects of radiotherapy in head and neck region, further studies are nee ded to widely disseminate acute oral manifestations in irradiated patients.
\end{abstract}

Keywords: Oral Mucositis. Head and Neck Neoplasms. Radiotherapy. Xerostomia.

\section{Resumo}

A utilização de radiação ionizante, no câncer de cabeça e pescoço, afeta não somente células malignas, mas também tecidos sadios, o que promove diversos efeitos colaterais em cavidade oral, classificados em agudos ou tardios. Dentre os efeitos agudos, a muc osite oral, xerostomia, hipossalivação, disgeusia e disfagia apresentam papel de destaque. O presente trabalho visou realizar uma revisão narrativa de literatura sobre a radioterapia em região de cabeça e pescoço como modalidade terapêutica para o câncer nesta região e as principais manifestações orais agudas decorrentes da radiação ionizante e seus respectivos tratamentos. Tratou-se de revisão de literatura do tipo exploratória, através das bases de dados da Scielo, Pubmed, Medline e sites institucionais utilizando o cruzamento dos descritores em inglês e português "neoplasias de cabeça e pescoço", "radioterapia", "mucosite oral", "xerostomia", "disgeusia" e "disfagia". De acordo com os critérios estabelecidos, um total de 46 artigos e 2 sites institucionais foram selecionados nas bases de dados, e 1 livro foi acrescentado por apresentar relevância sobre a temática em questão. Os resultados demonstram que a mucosite oral é o efeito agudo mais pre valente e apesar de ter impacto direto na qualidade de vida, não há tratamento considerado padrão ouro para esta condição. A disfag ia, xerostomia, hipossalivação e disgeusia são manifestações comuns em pacientes irradiados, e apresentam diversas modalidades terapêuticas que podem ser empregadas. Dada à importância dos efeitos colaterais da radioterapia de cabeça e pescoço, torna-se necessária a realização de mais estudos afim de divulgar amplamente as manifestações orais agudas em pacientes irradiados.

Palavras-chave: Mucosite Oral. Neoplasias de Cabeça e Pescoço. Radioterapia. Xerostomia.

\section{Introduction}

Cancer is one of the diseases that most affects people in the world, and represents the second leading cause of death worldwide. In view of the diversity of factors that cause this disease, early diagnosis contributes to better survival and use of less aggressive methods, which promotes better comfort and quality of life to the patient ${ }^{1,2}$.

Head and neck cancer corresponds to the presence of malignant tumor in the upper aerodigestive tract, and according to the National Cancer Institute (INCA), estimates point to 600 thousand new cancer cases between 2018-2019, 50 with predominance of malignant neoplasm in the head and neck region in men over 50 years of age ${ }^{3}$. Smoking, alcoholism, family history, environmental factors and exposure to carcinogenic agents are some of the conditions that predispose and favor the progression of this disease ${ }^{4}$.

The most used therapeutic modalities for the treatment of head and neck cancers are surgery, radiotherapy and chemotherapy, which can be used in a combined or separate manner. Radiotherapy is the use of corpuscular or electromagnetic ionizing radiation, which can promote the inhibition and/or destruction of tumor cells. Although its action mechanism is effective on malignant cells, this therapy is not selective, since it also acts on normal cells, which results 
in significant side effects in the oral cavity ${ }^{5,6}$.

Side effects from radiotherapy in the head and neck region may be acute or late. The most prevalent acute oral manifestations include oral mucositis, xerostomia, hyposalivation, dysgeusia and dysphagia, which contribute to a decline in the quality of life of oncologic patients ${ }^{7-9}$. Among these changes, mucositis is one of the most frequent side effects in irradiated patients, with incidence rates that can reach $90 \%$ of the cases, which is characterized by the development of painful inflammatory lesions that can affect any site of the oral cavity ${ }^{10}$.

In view of the foregoing, the present study aims to conduct a narrative literature review on radiotherapy in the head and neck region as a therapeutic modality for cancer in this region and the main acute oral manifestations and their respective treatments.

\section{Development}

\subsection{Methodology}

This is a narrative literature review of exploratory nature based on scientific articles, institutional sites and books in English and Portuguese, published between 2009-2019. The articles were searched in the database: Scielo, Medline, PubMed and institutional sites, from October 2018 to May 2019, based on DECS descriptors crossings in English and Portuguese: "head and neck neoplasms" and "head and neck neoplasms", "radiotherapy" and "radiotherapy", "oral mucositis" and "oral mucositis", "xerostomia", "dysgeusia" and "dysgeusia", "dysphagia" and "dysphagia".

The inclusion criteria established were: publication on the proposed theme of the last 10 years; scientific articles written in the English and Portuguese languages; books of extreme relevance to the subject in question. The exclusion criteria used were journals that did not address the subject in a clear way. During the research, 46 scientific articles were consulted and selected, and 5 articles of choice were presented outside the selection curve because it was published in a period prior to the established, however, with relevant content for familiarization with the theme and its development, being incorporated for this revision. In addition, two institutional sites (National Cancer Institute - INCA and World Health Organization - WHO) and one book were included, totaling 49 surveys included in the study.

\subsection{Cancer and Radiotherapy}

The prevalence of cancer cases in recent years due to a diversity of factors is very extensive. In Brazil, there is a high number of cases of head and neck cancer, which can be highlighted by an estimate for 2018 of 11,200 new cases in the oral cavity in males and 3,500 in females, and in the larynx 6,390 in males and 1,280 in females ${ }^{2,3}$.

As for the epidemiological profile, patients with malignant neoplasms in the head and neck region who are submitted to radiotherapy show predominance in males aged over 50 years, as it can be seen in the study by Bishop et al. ${ }^{11}$, performed with 35 patients, of whom $82.9 \%$ were male and only $17.1 \%$ were female, $37.1 \%$ were aged between 50 and 69 years.

Cancer, when it affects the upper aerodigestive tract, has consequences for the patients' general health, not just for the oral cavity. Some factors are definitive for the choice of treatment, so it is necessary to individualize the investigation in each case. Usually, the alcoholic and smokers are among the most affected, since they are part of the main cancer risk group in this region. However, other conditions contribute to the cancer advancement, such as family history, unhealthy eating and exposure to other carcinogenic agents ${ }^{4}$.

When discovered in the initial phase, the chances of efficacy in the treatment increase significantly. Late discovery due to lack of information or negligence of signs and symptoms, lack of oral hygiene, harmful habits, and previous diseases corroborate for more invasive methods that mutilate the patient ${ }^{4,12}$.

Radiotherapy is a therapeutic modality often used for the treatment of head and neck cancers, associated with surgery and/or chemotherapy. Ionizing radiation can be corpuscular when using particles such as protons, electrons, neutrons and alpha, or electromagnetic, that range from gamma rays to short, medium or long waves. They are used in radiotherapeutic treatment through indirect action, which constitutes alteration of the genetic material of malignant cells, which damage them through the production of free radicals or in a direct way, which causes cell death through direct action in $\mathrm{DNA}^{5,13}$.

Although the number of sessions is variable according to tumor location, histological subtype, staging and radiation technique used, the treatment is usually 1.8 to 2 grays (Gy) per fraction in sessions 5 times a week, with total dose ranging from 50 to $70 \mathrm{~Gy}$, which can last from 6 to 7 weeks. Areas where doses greater than $60 \mathrm{~Gy}$ are administered and that include larger salivary glands are the ones that present the greatest risk of complications. Fractionation reduces toxicity gradually and allows better results, because cells will respond late and treatment will be more effective. Radiotherapy may be curative, when it represents the main therapeutic modality used, in cases where surgery is not possible; palliative, which reduces signs and symptoms, in an attempt to alleviate them; and adjuvant, which acts through destruction of the remaining malignant cells after surgery ${ }^{6,14,15}$.

In radiation therapy with modulated beam intensity (IMRT), healthy structures can be preserved if high doses are required. Image guided radiotherapy (IGRT) is used in association with stereotactic radiation therapy, where the hypofractionation technique is applied to reduce tumor cells, being administered in precise locations one or fewer fractions of high radiation doses ${ }^{16}$.

Usually, patients submitted to radiotherapy in the head and neck region are prone to several changes in the oral cavity and 
the attached regions, which bring clinical consequences, such as oral mucositis, hyposalivation, xerostomia, opportunistic infections, trismus, difficulty in verbal communication, swallowing and breathing. Esthetic changes also negatively affect the individual's daily life, which makes the acceptance of the therapy more complex ${ }^{6,17}$. These changes may occur during or after radiotherapy treatment, classified as having acute and late effects, respectively, which directly affects the quality of life of these patients.

As a result of these results, it is essential that these patients be strictly controlled so that the discontinuation of oncologic treatment is not necessary ${ }^{18}$.

During the process of antineoplastic treatment, patients find a temporary difficulty in feeding, depending on the response to radiotherapy. They also present adverse reactions which include degrees of mucositis, dysphagia, xerostomia, dysgeusia, nausea, vomiting and odynophagia. ${ }^{7}$ In view of this, not only the surgeon-dentist is important, but a multidisciplinary team is essential for care before, during and after oncologic treatment.

As the appearance of these undesirable effects in the oral cavity during radiation therapy is common and expected, the professional acts in the orientation of hygiene, removal of infectious foci prior to radiation therapy treatment, in addition to preventive measures and care for the complications that are already installed, biofilm and infectious processes control, which provides greater comfort to the affected patients ${ }^{6,19}$.

\subsection{Major Acute Oral Manifestations}

\subsubsection{Oral Mucositis (OM)}

The Oral cavity is covered by a membrane that consists of an epithelial layer and a layer of connective tissue, and its main functions are of coating and protection. Irradiation causes severe tissue change. When cell death occurs, there is a total or partial discovery of the mucosa and when the cells cannot recover, inflammatory lesions called oral mucositis (OM) occur $^{10,20}$. OM presents with edema, erythema, desquamation, ulcers and formation of pseudo membranes in the oral cavity. In addition, patients report bleeding, painful symptoms and burning sensation ${ }^{20,21}$.

World Health Organization - $\mathrm{WHO}^{22}$ recommends a graduation scale for the OM classification according to the signs and symptoms presented by cancer patients. Degree 0 indicates absence of symptomatology; degree 1 presents as erythema and associated painful symptomatology; degree 2 evolves to painful ulcers; however, it allows normal feeding, which can be solid and liquid; degree 3 persist and ulcers evolve, and the patient is only able to maintain a liquid diet; and degree 4, where ulcers make it impossible for the patient to feed, so parenteral/enteral nutrition is necessary (Chart 1).

Table 1 - OM degrees according to the World Health Organization (who $)^{22}$ and the National Cancer Institute ( NCI) ${ }^{23}$ scales

\begin{tabular}{|l|c|c|c|c|c|c|}
\hline & Degree 0 & Degree 1 & Degree 2 & Degree 3 & Degree 4 & Degree 5 \\
\hline $\begin{array}{l}\text { Scale } \\
\text { Scale }\end{array}$ & $\begin{array}{c}\text { Absence of } \\
\text { symptomatology }\end{array}$ & $\begin{array}{c}\text { Erythema } \\
\text { and painful } \\
\text { symptomatology }\end{array}$ & $\begin{array}{c}\text { Painful ulcers } \\
\text { allow solid and } \\
\text { liquid feeding }\end{array}$ & $\begin{array}{c}\text { Ulcers, ingesting } \\
\text { liquids is the only } \\
\text { possibility }\end{array}$ & $\begin{array}{c}\text { Parenteral/enteral } \\
\text { nutrition }\end{array}$ & - \\
\hline $\begin{array}{l}\text { Scale } \\
\text { NCI }\end{array}$ & Intact mucosa & Erythema & $\begin{array}{c}\text { Ulcers or irregular } \\
\text { pseudo- } \\
\text { membranes }\end{array}$ & $\begin{array}{c}\text { Ulcers with } \\
\text { bleeding to small } \\
\text { traumas }\end{array}$ & $\begin{array}{c}\text { Ulcers with } \\
\text { spontaneous } \\
\text { bleeding and } \\
\text { necrosis }\end{array}$ & Death \\
\hline
\end{tabular}

Source: Research data.

The Common toxicity criteria of the National Cancer Institute - $\mathrm{NCI}^{23}$ also evaluates the MO according to its severity, and represents one of the most widely used scales for oncology centers. In degree 0 the mucosa is intact; degree 1 is manifested as erythema; degree 2 evolves to irregular ulcers or pseudo membranes; in degree 3 , ulcers manifest and there may be bleeding with small trauma; in degree 4, ulcers present spontaneous bleeding and necrosis, and degree 5, death (Chart $1)$.

Pain and difficulty in feeding are obviously constant before the OM signs, which makes it necessary to change the feeding to a diet, preferably liquid and pasty, or even with the aid of a nasogastric tube. As radiotherapy treatment evolves, oral lesions may worsen, which makes patient nutrition impossible, and with this the need to change the treatment plan or even the interruption until the signs improvement ${ }^{21}$.

In a retrospective study carried out by Zhenhao et al. ${ }^{24}$, whose objective was to investigate the main risk factors associated with radio-induced $\mathrm{OM}$ in cancer patients in the head and neck region, it was possible to observe that all patients $(n=80)$ showed some degree of mucositis, 69\% developed degree 2 and 3 of $\mathrm{OM}$ according to the Radiotherapy and Oncology scale Group (RTOG), which includes the presence of lesions associated with moderate to severe pain, with the need for potent analgesics. Smoking and radiation dose were the factors that contributed most to the potentiation of the mucositis clinical profile.

Low-power laser therapy acts on cell bio stimulation that promotes analgesic, anti-inflammatory and healing effects. In addition, it has the protective function in the buccal tissues, especially in the salivary glands ${ }^{14,25}$. In a study carried out by Oton-Leite et $a .^{14}, 60$ patients who received radiotherapy in the head and neck regions were evaluated, and were divided into experimental and control groups. The experimental group received low-power laser application in the oral cavity, and in the control group, the laser light was inactive, however there 
was simulation of the application. The applications were performed all 35 days of radiotherapy. Patients in the control group presented more severe mucositis lesions compared to the laser group ( $p>0.001)$, however, both groups showed some degree of OM.

The use of natural agents for the management of several diseases has been a prominent role in recent years due to the numerous beneficial properties of these agents, low cost and easy access ${ }^{26}$. The fact that $\mathrm{OM}$ does not present therapy that is considered a gold standard, several natural agents have been studied for this purpose, such as Aloe Vera ${ }^{27}$, honey ${ }^{28}$, propolis $^{29}$ and chamomile ${ }^{30}$. However, more research is needed to prove the real effectiveness of these agents.

$\mathrm{CHO}$ et al. ${ }^{28}$, in a systematic review with meta-analysis, observed that the preventive administration of honey in patients who received radiotherapy in head and neck regions was beneficial, since there was a reduction in the incidence from moderate to severe OM, in addition to the ability to reduce bacterial colonization. Despite the positive effects, these results need to be seen with caution, since there are few studies that address this therapy, with more research needed to determine efficacy.

According to De Mendonca ${ }^{29}$, propolis may be used as an auxiliary method for the prevention and reduction of symptoms caused by OM, due to its ability to present antimicrobial activity, besides being anti-inflammatory and healing. The wide effectiveness allows its use in all degrees of this oral manifestation.

Carl and Emrich ${ }^{30}$ evaluated 98 patients, of whom 20 received radiotherapy at the head and neck regions. Protocol of oral care was used based on the use of Kamillosan ${ }^{\circledR}$ oral rinse, which was prepared from the chamomile flower. Patients were instructed to mix 10-15 drops of Kamillosan ${ }^{\circledR}$ liquid in $100 \mathrm{ml}$ of water and rinse vigorously at least three times a day. The results showed that there was a delay in the appearance of radio-induced OM, in addition to less aggressive lesions in patients who used this natural agent. No toxicity, unpleasant taste or irritation was observed. Despite the chamomile positive results, due to the insufficient number of articles that address the use of chamomile in irradiated patients, further studies are necessary to prove the efficacy of this agent, as well as other natural products, such as honey, propolis and aloe Vera.

According to Ahmadi ${ }^{27}$, Aloe Vera has immunomodulatory, anti-inflammatory, healing properties and stimulates the increase in collagen formation. In addition to being used to prevent this condition, the oral rinse may be used as an alternative method to treat radiotherapy-induced OM in the head and neck region, in addition to reducing oral candidiasis.

The Multinational Association for Supportive Care of Cancer and International Society of Oral Oncology (MASCC)/OOIS) address the main guidelines for clinical practice with MO prevention and treatment measures. Among the recommendations, care with oral hygienization is highlighted for all types of malignant neoplasms, by brushing twice a day; use of low-power laser on the red wavelength for the prevention of radio-induced OM; systemic and topical morphine (oral $2 \%$ morphine rinse) for the control of painful symptoms caused by mucositis and zinc supplementation for patients with malignant neoplasms in the head and neck region submitted to radiotherapy, since this compound has an antioxidant effect ${ }^{30}$.

\subsubsection{Xerostomia and Hyposalivation}

Saliva is a mixed fluid produced by the major and minor salivary glands. Among its main functions are cleaning, mouth humidification, speech aid, food swallowing, and buffer capacity, maintaining a balanced $\mathrm{pH}$. Xerostomia is the subjective sensation of dryness of mouth, whereas hyposalivation represents the qualitative decrease in salivary flow, which may be due to changes in health status, nutritional, emotional, metabolic, locoregional radiotherapy, local factors such as decreased mastication, smoking, oral breathing or drug use, such as diuretics, antidepressants, hypoglycemic agents, antihypertensive and antiallergic drugs ${ }^{8,31}$.

Usually, the patient presents a reduction in salivary flow and the saliva remnant is thick or foamy in the form of threads. The tongue dorsum is frequently cracked with atrophied filiform papillae, dry mucosa, cracked lips and mouth angle with fissures. Patients with salivary gland disorders are also more likely to develop candidiasis, and when these changes occur due to radiotherapy, it is common to develop caries in the cervical or root region ${ }^{32}$.

Xerostomia and hyposalivation are complications that usually manifest in an acute manner during radiation treatment, and that can remain after the radiotherapy treatment completion. As a result of these side effects, the patient's quality of life is impaired, and even usual practices, such as eating and speaking, cause discomfort ${ }^{33}$.

Among the treatments and prevention measures are the diet change through the prioritization of cold foods and suspension of those spicy and with hardened consistency, use anti-xerostomia dentifrice containing salivary enzymes, such as lactoperoxidase, glucose oxy and lysozyme, to hygienize the oral cavity. Salivary stimulators such as sugarfree chewing gum, based on xylitol or sorbitol, also play an important role in reducing this $\operatorname{sign}^{32,34}$. Transcutaneous electrical nervous stimulation has already been shown to be effective as an auxiliary method for reducing xerostomia and improving salivary flow when used concomitantly with radiotherapy treatment ${ }^{35}$.

Low-intensity laser therapy acts satisfactorily in the salivary glands stimulation in irradiated patients at the head and neck region ${ }^{14,36}$. Palma et al. ${ }^{35}$, carried out a prospective study with 29 patients, all of whom reported xerostomia after the radiotherapy treatment. A total of 24 low intensity laser sessions were performed in the parotid, submandibular and sublingual glands twice a week for three consecutive 
months. The patients were evaluated with stimulated and non-stimulated sialometry in the first and last session of the laser therapy. The results showed that there was a significant increase in salivary production and $\mathrm{pH}$ after laser treatment, with a positive impact and improvement in the quality of life of these patients.

Pereira et $a l .^{37}$ evaluated 12 patients submitted to radiotherapy at the head and neck region and all of them presented xerostomia complaints. Sialometry was performed and the patients used pilocarpine, which is a parasympathetic agent that stimulates salivary flow, in the form of a $10 \mathrm{mg}$ tablet, 3 times a day. A total of four patients reported improvement in salivation with the use of pilocarpine, with a positive result in salivary tests; another 4 reported improvement in salivation with the use of medication, but without improvement of the results in salivary tests. Of the 12 patients, three of them had side effects, but without the need to interrupt the treatment, but four of them had significant effects and interrupted the treatment. The results indicate the positive effect of pilocarpine, however, in the presence of comorbidities, its use requires caution. Accordingly, Lalla et al. ${ }^{30}$, through MASCCISOO, reports that the use of pilocarpine may be beneficial in patients receiving radiotherapy for head and neck cancer and presenting hyposalivation.

\subsubsection{Dysgeusia}

Dysgeusia is an abnormal persistent taste alteration, produced by a systemic disorder that affects more than one third of the patients under radiotherapy treatment at the head and neck region. Modified taste is one of the main symptoms affecting these patients. Dysgeusia, as well as dysphagia, xerostomia and hyposalivation, are acute and also late manifestations of radiotherapy treatment ${ }^{38,39}$.

Cancer patients may develop dysgeusia due to a number of factors, to which OM can be cited, which causes a direct lesion to the mucosa, radiotherapy, which damages the cells responsible for the gustative reception and makes evident the sensation of metallic and bitter flavors, drugs that directly influence taste and odor receptors, nutritional deficiency, poor nutrient absorption, salivary gland disorders, opportunistic infections, and zinc deficiency ${ }^{38-40}$.

A descriptive cohort study carried out with 22 patients with head and neck cancer showed that all the patients presented dysgeusia after radiotherapy treatment, and $72.2 \%$ with total loss of taste. Bitter and salty flavors were the most affected, while sweet and sour were reported less frequently ${ }^{41}$.

In these patients, awareness of the need to eat is important so that there is no malnutrition, since psychological and emotional factors influence feeding. It is also important to encourage the consumption of pleasant foods, change the consistency of foods according to acceptance, make them liquid if necessary, fragment the diet from six to eight meals a day, prepare pleasant and colorful dishes visually, guide them to remember the flavors of food before eating them and prefer the strongest flavors. In addition, studies show that zinc administration contributes to taste improvements ${ }^{42,43}$.

\subsubsection{Dysphagia}

Deglutition is a process that the displacement of saliva, liquids or foods occurs from the oral cavity that passes through the pharynx, esophagus, to the stomach, and keeps the individuals nourished and hydrated. When there is a change in swallowing, it may trigger dehydration, malnutrition, entry of food into the airways, or even death. Dysphagia can be described as a change in the food bolus transport ${ }^{9}$.

Dysphagia may be caused by changes in the oral cavity or structures such as esophageal sphincter, drugs for radiotherapy treatment, in addition to procedures such as orotracheal intubation, tracheostomy, gastroesophageal reflux disease ${ }^{44}$.

Before the radiotherapy treatment, patients with head and neck cancer present dysphagia as a common consequence, to whom it is possible to observe high rates of malnutrition due to the difficulty feeding, since radiotherapy atrophies the muscles of the region ${ }^{45,46}$.

Chavoni, Silva and Ramos ${ }^{47}$, carried out a study with 54 patients, of whom 38 presented cancer in the pharynx region and oral cavity in an advanced stage. All of them developed dysphagia with consequent weight loss. Similarly, in a study by Bishop et al. $^{11}$, with a similar population of oncologic patients, $60 \%$ presented dysphagia as one of the most common consequences, below only the OM.

Cancer patients may have varied nutritional needs depending on the activity of the disease, type and location of the tumor, and need weight gain. Since dysphagia makes swallowing difficult, it is necessary to make the patient aware that it is essential to feed, to modify the food consistency in cases of difficulty when ingesting solids, to fractionate the diet, to guide them to avoid hard and dry foods with predilection to the most moistened ones, ingested liquids along with meals to facilitate chewing and swallowing, keep the headboard high, and in cases that make oral feeding impossible, methods such as the use of nasoenteral, nasogastric probes, or even parenteral route can be used. The muscles that are part of swallowing can be rehabilitated by exercises and maneuvers that provide improved strength and coordination. The use of oral supplementation of high-quality proteins should be administered to patients who are malnourished or have low dietary intake $\mathrm{in}^{46-48}$.

In order to avoid these adverse effects resulting from radiotherapy at the head and neck region, the presence of a dental surgeon in the multidisciplinary team is of extreme importance, due to his or her function is to prevent and treat these effects, since they have the ability to alter or even interrupt radiotherapy therapy, which directly affects the quality of life of these patients, due to high morbidity and mortality $^{49}$. 


\section{Conclusion}

Radiotherapy, one of the main therapeutic modalities used for oncologic treatment, results in devastating side effects in the oral cavity, and the most prevalent acute manifestations in this region are $\mathrm{OM}$ and salivary gland disorders, which cause xerostomia and hyposalivation.

The main therapeutic modalities used for the management of adverse effects present the ability to minimize the main acute effects, improving the quality of life of cancer patients. It is of fundamental importance to insert the dental surgeon into the multidisciplinary team, since his or her presence in this process will minimize these side effects.

\section{References}

1. Torre LA, Bray F, Siegel RL, Ferlay J, Lortet-Tieulent, Jemal L. Global Cancer Statistics, 2012. CA Cancer J Clin 2015;65:87-108. doi: https://doi.org/10.3322/caac.21262

2. Menezes AC, Rosmaninha E, Raposo B, Alencar MJS. Abordagem clínica e terapêutica da mucosite oral induzida por radioterapia e quimioterapia em pacientes com câncer. Rev Bras Odontol 2014;71(1):35-8.

3. Brasil. Ministério da saúde. Instituto nacional do câncer José Alencar Gomes da Silva (INCA). Estimativa 2018. Rio de Janeiro: INCA, 2018.

4. Galbiatti ALS, Padovani-Junior JA, Maníglia JV, Rodrigues CDS, Pavarino EC, Goloni-Bertolllo EM. Câncer de cabeça e pescoço: causas, prevenção e tratamento. Braz J Otorhinolaryngol 2013;79(2):239-47. doi: http://dx.doi. org/10.5935/1808-8694.20130041

5. Beech N, Robinson S, Porceddu S, Batstone M. Manejo odontológico de pacientes irradiados para câncer de cabeça e pescoço. Aust Dent J 2014;50(1):20-8. doi: https://doi. org/10.1111/adj.12134

6. Freitas DA, Caballero AD, Pereira MM, Oliveira SKM, Silva GP, Hernández CIV. Sequelas bucais da radioterapia de cabeça e pescoço. Rev CEFAC 2011;13(6):1103-8. doi: http://dx.doi.org/10.1590/S1516-18462011005000071

7. Takara TFM, Morikawa W, Rivoir Vivacqua R, Trevisan C, Tieko Ando E, Machado de Carvalho G, et al. Avaliação nutricional em pacientes com câncer de cabeça e pescoço. Rev Bras Cir Cabeça Pescoço 2012;41(2):70-4.

8. Miziara ID, Mahmoud A. Síndrome da boca seca. Rev Hosp Univ Pedro Ernesto, UERJ 2012; 68-9.

9. Barros APB, Portas JG, Queija DS. Implicações da traqueostomia na comunicação e na deglutição. Rev Bras Cir Cabeça Pescoço 2009;38(3):202-7.

10. PS SK, Balan A, Sankar A, Bose T. Mucosite oral induzida por radiação. Indian J Palliat Care 2009;15:95-102. doi: 10.4103/0973-1075.58452

11. Bispo MS, Nascimento DS, Dantas JBL, Lima HR, Medrado ARAP, Carrera M, et al. Frequência de comorbidades associadas ao tratamento radioterápico de cabeça e pescoço. Rev Cienc Med Biol 2018;17(2):185-9. doi: 10.9771/cmbio. v17i2.27445

12. Paiva MDEB, Dibiase RCCG, Moraes JJC, Ângelo AR, Honorato MCTM. Complicações orais decorrentes da terapia antineoplásica. Rev Odonto 2010;46(1):48-55.

13. Brandão Júnior FA. Radiações e radiações ionizantes: mitos e verdades. Educ Tecnol 1997;2(2):39-44.

14. Oton-Leite AF, Arantes LSA, Morais MO, Pinezi JCD, Leles CR, Silva MAGS. Effect of low level laser therapy in the reduction of oral complications in patients with cancer of the head and neck submitted to radiotherapy. Spec Care Dentist 2013;33(6):294-300. doi: https://doi.org/10.1111/j.17544505.2012.00303.x

15. Bhide AS, Nutting CM. Recent advances in radiotherapy. BMC Medicine 2010;8(25). doi: https://doi.org/10.1186/17417015-8-25

16. Salvajoli JV. O papel da radioterapia no tratamento do câncer - avanços e desafios. Rev Onco 2012; 32-36.

17. De Paula JM, Sawada NO. Qualidade de vida relacionado à saúde de pacientes com câncer em tratamento radioterápico. Rev Rene 2015;16(1):106-13. doi: 10.15253/21756783.2015000100014

18. Caccelli EMN, Pereira MLM, Rapoport A. Avaliação da mucosite e xerostomia como complicações do tratamento de radioterapia no câncer de boca e orofaringe. Rev Bras Cir Cabeça Pescoço 2009;38(2):80-3.

19. Pozzobon JL, Ortiz FO, Braun K, Unfer B. Complicações bucais dos tratamentos de câncer de cabeça e pescoço e de malignidades hematológicas. RFO UPF 2011;16(3):342-6. doi: https://doi.org/10.5335/rfo.v16i3.1849

20. Sonis ST. Pathobiology of oral mucositis: novel insights and opportunities. J Support Oncol 2007;5(9 Suppl 4);3-11.

21. Spezzia S. Mucosite oral. J Oral Invest 2015;4(1):14-8. doi: $10.18256 / 2238-510 \mathrm{X} / \mathrm{j}$

22. WHO - World Health Organization. Handbook for reporting results of cancer treatment. Geneva: World Health Organization, 1979:15-22. doi: https://apps.who.int/iris/ handle/10665/37200

23. Common Toxicity Criteria Manual. Common Toxicity Criteria, Version 2.0. National Cancer Institute, 1999: 1-31.

24. Zhenchao T, Jin G, Liting Q, Yifan H, Yan Z, Liping Y, et al. Factors associated with acute oral mucosal reaction induced by radiotherapy in head and neck squamous cell carcinoma. Medicina 2017;96(50):1-5. doi: 10.1097 / MD.0000000000008446.

25. Costa GS, Oliveira FP, Sá LLF, Calaça MB, Sousa ACO. Tratamento de mucosites associadas à xerostomia. Rev Uningá 2017;29(3):114-7.

26. AhmadiA. Potential prevention: aloe vera mouthwash may reduce radiation-induced oral mucositis in head and neck cancer patients. Chin J Integr Med 2012;18(8):635-40. doi: 10.1007/s11655-012-1183-y

27. Cho HK, Jeong YM, Lee HS, Lee YJ, Hwang SH. Effects of honey on oral mucositis in patients with head and neck Cancer: a meta-analysis. Laryngoscope 2015;125(9):208592. doi: 10.1002/lary.25233

28. De Mendonça ICG. Propolis as an adjunct to prevention and treatment of radiotherapy- and chemotherapy-induced oral mucositis. Nurs Palliat Care 2016;1(5):97-100. doi: 10.15761/NPC. 1000125

29. Carl W, Emrich LS. Management of oral mucositis during local radiation and systemic chemotherapy: A study of 98 patients. J Prost Dent 1991;66(9):361-9. doi: 10.1016/00223913(91) 90264-w

30. Lalla RV, Bowen J, Barasch A, Elting L, Epstein JB, Keefe DM, et al. MASCC/ISOO Clinical Practice Guidelines for 
the management of mucositis secondary to cancer therapy. Cancer 2014;1453-61. doi: 10.1002 / cncr.28592

31. Spielmann N, Wong DT. Saliva: diagnostics and therapeutic perspectives. Oral diseas 2010;17(4):345-54. doi: 10.1111/j.1601-0825.2010.01773.x

32. Mod D, Mod H, Jha A. Oral and dental complications of head and neck radiotherapy and theyr management. J Nepal Health Res Counc 2013;11(25):300-4.

33. Jundong G, Zhu S, Li X, Wu H, Li Y, Hua F. Effect of amifostine in head and neck cancer patients treated with radiotherapy: a systematic review and meta-analysis based on randomized controlled trials. Plos one 2014;9(5):e95968. doi: 10.1371/journal.pone.0095968

34. Pinna R, Campus G, Cumbo E, Mura I, Milia E. Xerostomia induced by radiotherapy: an overview of the physiopathology, clinical evidence, and management of the oral damage. Ther Clin Risk Manag 2015; 11:171-188. doi: 10.2147/TCRM. S70652

35. Lakshman AR, Babu GS, Rao S. Evaluation of effect of transcutaneous electrical nerve stimulation on salivary flow rate in radiation induced xerostomia patients: a pilot study. J Can Res Ther 2015;11(1):229-33. doi: 10.4103/09731482.138008.

36. Palma LP, Gonnelli FAS, Marcucci M, Dias RS, Giordani AJ, Segreto RA et al. Impact of low-level laser therapy on hiposalivation, salivar ph, and quality of life in head and neck cancer patients post-radiotherapy. Lasers Med Sci 2017; doi 10.1007/s10103-017-2180-3.

37. Pereira PSG, Chone CT, Sampaio MPA, Crespo AN. Xerostomia pós-radioterapia em cabeça e pescoço: tratamento tópico oral com pilocarpina. Rev Bras Cir Cabeça Pescoço 2012;41(4):178-180.

38. Bressan V, Bagnasco A, Aleo G, Catania G, Zanini MP, Timmins $\mathrm{F}$ et al. The life experience of nutrition impact symptoms during treatment for head and neck cancer patients: a systematic review and meta-synthesis. Support Care Cancer
2017;25(5):1699-1712. doi: 10.1007/s00520-017-3618-7

39. Ponticelli E, Clari M, Frigerio S, De Clemente A, Bergese I, Scavino E, et al. Dysgeusia and health- related quality of life of cancer patients receiving chemotherapy: a cross- sectional study. Eur J Cancer Care 2017;26(2):1-7. doi: 10.1111/ ecc. 12633

40. Bloise R, Davis MP. Dysgeusia. J Palliat Med 2016;19(4): doi 10.1089/jpm.2016.0017.

41. Baharvand M, Shoaleh Saadi N, Barakian R, Moghaddam EJ. Taste alteration and impact on quality of life after head and neck radiotherapy. J Oral Pathol Med 2012;42(1):106-12. doi: 10.1111/j.1600-0714.2012.01200.x

42. Fujii H,Hirose C, Ishihara M, Lihara H, Imai H, Tanaka Y, et al. Improvement of dysgeusia by polaprezinc, a zinc-l-carnosine, in outpatients receiving cancer chemotherapy. Anticancer Res 2018;38:6367-73. doi: 10.21873/anticanres. 12995

43. Pinho NB. Consenso nacional de nutrição oncológica temáticas do paciente adulto. Rev Ampl Atual 2018;2:160-82.

44. Matsuo K, Palmer JB. Anatomy and Physiology of Feeding and Swallowing - Normal and Abnormal. Phys Med Rehabil Clin N Am 2009;9(4):691-707. doi: 10.1016/j. pmr.2008.06.001

45. Smiderie CA, Gallon CW. Desnutrição em oncologia: revisão de literatura. Rev Bras Nutr Clin 2012;27(4):250-6.

46. González EC. Consequências e tratamento da disfagia. Suplementos Nutr Hosp 2009;2(2):66-78.

47. Chavoni RC, Silva PB, Ramos GHA. Diagnóstico nutricional de pacientes do serviço de cabeça e pescoço e sua relação com a disfagia em um hospital oncológico do Paraná. Rev Bras Cir Cabeça Pescoço 2014;43(1):35-41.

48. Jotz GP, Dornelles S. Distúrbios da deglutição. Rev Hosp Univ Pedro Ernesto, UERJ 2012;11:70-6.

49. De Paula Eduardo F, Bezinelli L, Correa L. Odontologia Hospitalar. Barueri: Manole; 2019. 